\title{
Decay resistance in Dicorynia guianensis Amsh.: analysis of inter-tree and intra-tree variability and relations with wood colour
}

\author{
Nadine AMUSANT ${ }^{a *}$, Jacques BEAUCHENE ${ }^{\mathrm{b}}$, Mériem FOURNIER ${ }^{\mathrm{c}}$, Gérard JANIN ${ }^{\mathrm{d}}$ \\ Marie-France THEVENON ${ }^{\mathrm{a}}$
a CIRAD Forêt/Forest Products Programme, 73 rue JF Breton, 34398 Montpellier Cedex 5, France b CIRAD Forêt/Forest Products Programme, BP 701, 97310 French Guiana, France d Universidade de Brasilia, Departamento de Enensharia Florestral, Brasilia D.F., Brazil \\ c UMR Écologie des forêts de Guyane, CIRAD-ENGREF-INRA, BP 709, 97310 French Guiana, France
}

(Received 22 November 2003; accepted 9 February 2004)

\begin{abstract}
Dicorynia guianensis Amsh. is very widespread in the forests of French Guiana and moreover is the leading species harvested in this area, but its main defect remains the great variability of wood durability, especially with respect to fungal decay. The aim of this work was to study this inter- and intra-tree variability in order to identify the parameters responsible for this variation (growth area, height and radial position) within the tree. The resistance decrease from the outer heartwood to the pith. Measurement of colour variation using the CIELAB (L*, $\left.a^{*}, b^{*}, C^{*}, h^{*}\right)$ system was performed at the intra-tree level to highlight the longitudinal and radial gradients of variation. Dicorynia guianensis becomes less red and dark from the outer to the inner heartwood and from the base to the top. Lastly, variations of colour and durability were correlated: the wood is less resistant the redder and darker it is.
\end{abstract}

Dicorynia guianensis / Amazonian wood / wood colour/decay resistance / heartwood / variability

Résumé - Variabilité de la durabilité inter-arbre et intra-arbre de Dicorynia guianensis - et relation avec la couleur. Dicorynia Guianensis Amsh. est une essence très répandue dans les forêts de Guyane française. C'est l'une des essences les plus exploitées cependant elle souffre d'un défaut majeur : une grande variabilité de sa durabilité naturelle à l'égard des champignons lignivores (Ascomycètes, Basidiomycètes). À travers l'étude de la variabilité inter-arbre et intra-arbre nous avons discuté de l'influence de paramètres tels : la localité, la taille de l'arbre, la hauteur et la position radiale sur la résistance naturelle. Dans une deuxième partie nous avons étudié l'influence de ces mêmes paramètres sur la mesure de la couleur (système CIELAB) du bois à l'échelle intra-arbre. Nous avons ainsi constaté que le paramètre " position radiale " était de loin le plus important à l'origine de la variabilité : Dicorynia guianensis est plus résistant du duramen interne vers le duramen externe ; moins rouge et moins sombre du duramen externe vers le duramen interne. Enfin, nous avons constaté que les variations de couleur et de durabilité chez Dicorynia guianensis étaient corrélées : le bois est d'autant plus résistant qu'il est moins rouge et plus clair sombre.

bois amazonien / couleur du bois / résistance à la pourriture / duramen / variabilité

\section{INTRODUCTION}

The variability of natural durability has frequently been studied with a view to understand and predict the behaviour of a wood in order to make optimum use of the resource. Dicorynia guianensis (basralocus) is of great interest to the local forestry industry in French Guiana, and represented 36\% of the extracted volume in 2001 [48, 50]. Many authors [13, 23, 51] showed that there is a significant variation in the decay susceptibility of this timber, with unfavourable consequences for classification of its durability. Early studies suggested that Eucalyptus spp. trees exhibit substantial variations in heartwood decay resistance within the same species $[38,39,41]$. This fact is usually attributed to the existence of radial and longitudinal gradients of decay resistance within the tree $[15,16]$. Others factors such as tree size $[7,34,41]$, growth rate $[11,42]$, and extractives contents in the heartwood $[12,14,17,20]$ help to explain the variations in resistance both between trees and within a single tree.

The objective of this work was therefore to study the variability of the natural durability of Dicorynia guianensis at intratree and inter-tree level. The relationship between colour and decay resistance has already been studied [10, 29]. Colour measurements were therefore performed to determine whether it was possible to correlate wood colour and durability, and use colour as an indicator in classifying the biological resistance of Dicorynia guianensis.

* Corresponding author: nadine.amusant@cirad.fr 


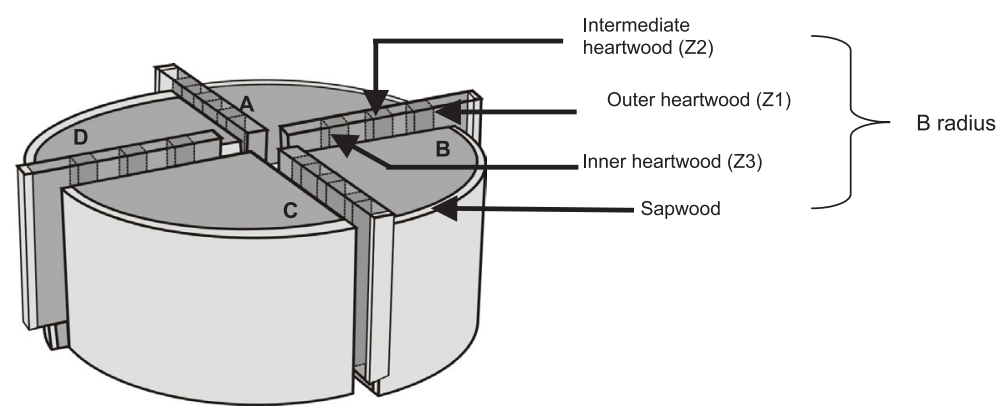

Figure 1. Localisation on stem cross section from which study blocks were taken for the intra-tree level.

\section{MATERIALS AND METHODS}

\subsection{Tree sampling}

\subsubsection{For intra-tree variability}

Test material was prepared from one tree (Dicorynia guianensis) especially collected for this work in the Counami Forest in French Guiana. Two levels of the tree (total height: $35 \mathrm{~m}$ ) were studied: $3 \mathrm{~m}$ and $15 \mathrm{~m}$ above ground. Wooden boards were cut following four radii positioned perpendicularly and noted A-B-C-D (Fig. 1). For each board from a radius, three $15 \times 25 \mathrm{~mm}$ sections $(\mathrm{R}, \mathrm{T})$ were cut from the outer heartwood (Z1), inner heartwood (Z3) and intermediate heartwood (Z2). Test specimens measuring $15 \times 25 \times 50 \mathrm{~mm}(\mathrm{R}, \mathrm{T}$, L) were cut from each sample obtained.

\subsubsection{For inter-tree variability}

$15 \times 25 \times 50 \mathrm{~mm}$ samples $(\mathrm{R}, \mathrm{T}, \mathrm{L})$ were cut from the outer and inner heartwood of 17 trees (Dicorynia guianensis) and one level of the tree were studied $(3 \mathrm{~m})$. All the trees were collected at two sites in French Guiana: Organabo and Tibourou. The Organabo site is a white sand forest, typical of the western part of French Guiana. At Tibourou, the soil is schistose and ferrallitic, typical of central and eastern French Guiana [2]. The average annual rainfall is also very different: $2600 \mathrm{~mm} /$ year and $3700 \mathrm{~mm} /$ year at Organabo and Tibourou respectively [2]. These two sites therefore represent the greatest possible difference in environmental conditions among the harvested forests of French Guiana. Dicorynia guianensis tree and wood quality is known to be very different at the two sites: the trees at Tibourou are larger with a high rate of compression failure. Their silica content and radial shrinkage are also greater than those of the trees from Organabo [2]. Table 1 shows the mensuration parameters characteristics of each sample.

\subsection{Decay test}

For intra-tree variability, the method used to test natural durability followed NF-EN 350-1 (AFNOR, 1994) and NF-EN 113 (AFNOR, 1996). The following fungi were selected: two white rots (Coriolus versicolor and Pycnoporus sanguineus) and a brown rot (Antrodia sp.). The decay tests were conducted as follows: for each test fungi, three replicate wood block were used for each height and each radial position. For inter-tree variability, two tropical fungi were used: Antrodia sp. (brown rot fungus) and Pycnoporus sanguineus (white rot fungus). In this case, the decay test was as follows: for each fungi, ten replicates were used for each tree, each radial position and height. Beech (Fagus sylvatica) samples of the same dimensions: $15 \times 25 \times$
Table I. Characteristics of the trees (inter-tree variability).

\begin{tabular}{cccc}
\hline Tree number & $\begin{array}{c}\text { Sapwood } \\
\text { thickness }(\mathrm{cm})\end{array}$ & $\begin{array}{c}\text { Diameter at breast } \\
\text { height }(\mathrm{cm})\end{array}$ \\
\hline O11 & 6.7 & 51 \\
& O12 & 5.0 & 62 \\
& O14 & 4.7 & 68 \\
& O17 & 3.3 & 73 \\
& O21 & 2.5 & 78 \\
& O29 & 5.8 & 65 \\
& O30 & 4.8 & 67 \\
& O31 & 6.3 & 60 \\
& O35 & 5.7 & 55 \\
& O36 & 7.1 & 59 \\
\hline \multirow{6}{*}{ Tibourou site } & T01 & 9.1 & 51 \\
& T02 & 7.8 & 48 \\
& T11 & 6.6 & 89 \\
& T19 & 2.0 & 73 \\
& T33 & 8.9 & 45 \\
& T40 & 3.7 & 87 \\
T49 & 1.8 &
\end{tabular}

$50 \mathrm{~mm}(\mathrm{R}, \mathrm{T}, \mathrm{L})$ were used as controls for the virulence of the strains (ten test blocks for each fungus). The test specimens (two blocks per flaks) were placed on test specimen supports over the fungal mycelium and incubated for 16 weeks in a decay chamber $\left(27^{\circ} \mathrm{C}-80 \%\right.$ relative humidity). At the end of the test, all the test specimens were removed, oven dried $\left(103 \pm 2{ }^{\circ} \mathrm{C}\right)$ to a constant weight and weighed to determine mass loss. The classification of natural durability was determined according to European standard NF-EN 350-1 (AFNOR, 1994). All the statistical analyses that follow were conducted on the abovedefined mass loss.

\subsection{Colour measurement}

Colour measurements were performed on the samples used for intra-tree durability, on which decay tests had been conducted. Colour was measured every $16 \mathrm{~mm}$ along the longitudinal-radial surface and the longitudinal-tangential surface (six measurements per sample), using a portable spectrophotometer (MICROFLASH DATACOLOR). 

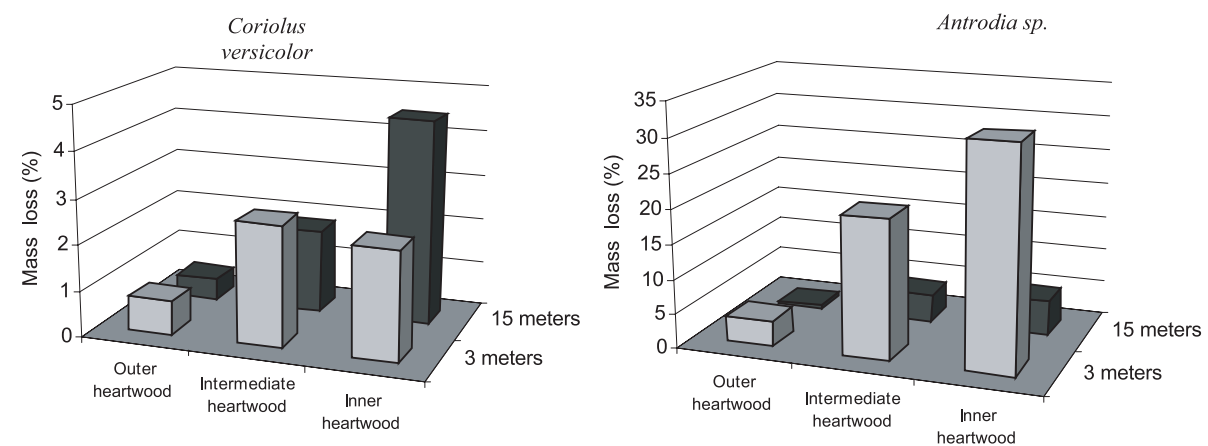

Figure 2. Influence of radial and height position on median mass loss (Coriolus versicolor and Antrodia sp.).

Illuminant D65 (represents daylight) and $10^{\circ} \mathrm{CIE}$ were used, parameters generally used to measure wood colour [24]. The surface observed was $59 \mathrm{~mm}^{2}$ (small opening of $8.7 \mathrm{~mm}$ ) and the specular reflection setting was excluded. The reflectance data were collected at $10 \mathrm{~nm}$ intervals over the visible spectrum (from 400 to $700 \mathrm{~nm}$ ). The reflectance readings were converted into $L^{*}, a^{*}, b^{*}, C^{*}$ and $h^{*}$ values, where $\mathrm{L}^{*}$ describes lightness along the lightness axis $(100=$ white or brightness; $0=$ black or darkness) of a colour a* value describes the redness $\left(a^{*}\right.$ positive value), or greenness $\left(a^{*}\right.$ negative value). Yellowness-blueness is shown by value $b^{*}: b^{*}$ positive for yellowness and $b^{*}$ negative for blueness. The angle $h^{*}$, hue, can be calculated by using values $a^{*}$ and $b^{*}: h^{*}=\operatorname{arctg}\left(b^{*} / a^{*}\right)$ in radian, or in degrees (deg). $\mathrm{C}^{*}$ (saturation) can be calculated by the formula $\mathrm{C}^{*}=$ $\left[\left(a^{*}\right)^{2}+\left(b^{*}\right)^{2}\right]^{1 / 2}$

Study of colour variability at intra-tree level will be realise according to two parameters: (i) radial position: three radial positions were selected: Z1, Z2 and Z3 (outer, intermediate and inner heartwood); (ii) height position: $3 \mathrm{~m}$ and $15 \mathrm{~m}$ above the ground.

\subsection{Statistical analysis}

The effects at intra-tree level of radial position and height on mass loss after exposition to fungi were studied by an analysis of variance (Anova). A second analysis of variance was calculated to evaluate the effect at inter-tree level of site, tree, radial position and height on mass loss after exposition to fungi. Values were considered statistically significant if $P<0.05$. Correlation coefficients were calculated to determine the relationship between colour parameters and durability at intra-tree level and between sapwood thickness, diameter and heartwood decay resistance at inter-tree level.

\section{RESULTS}

\subsection{Intra-tree variability: effect of radial and height position}

Figure 2 illustrates the intra-tree variability of durability observed with Dicorynia guianensis.

Using the calculation of the median mass loss rather than the mean in interpreting the results improves the reproducibility of the results, and reduces the impact of singular results that cannot be explained [49]. The median mass losses obtained respectively for each fungus are: $0.1 \%$ for Pynoporus sanguineus, $1.7 \%$ for Coriolus versicolor and $5.7 \%$ for Antrodia sp. Using the criterion of mass loss (as per standard EN 350-1, AFNOR,

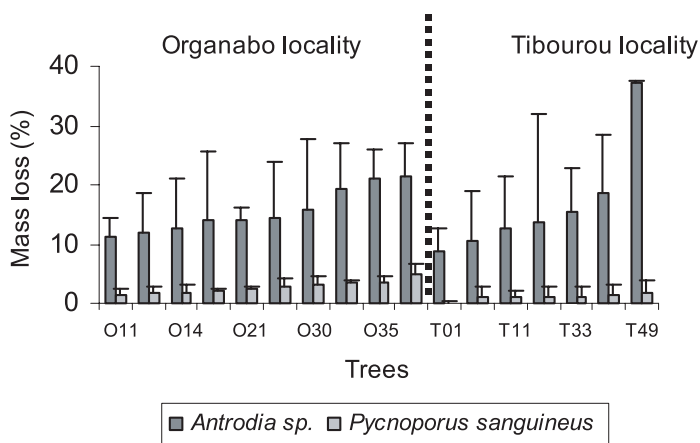

Figure 3. Inter-tree mean mass loss due to Antrodia sp. and Pycnoporus sanguineus according locality.

1994) classifies Dicorynia guianensis among durable species. The median mass loss obtained is between $5 \%-10 \%$ with the more virulent fungus (Antrodia sp.). Of the three test fungi used, the brown rot Antrodia sp. proved to be much more destructive on Dicorynia guianensis, which confirmed the observations of Déon [13] and Mateejcic [27]. A two factors analysis of variance ("effect of radial position" and "effect of height") of the mass losses due to the more virulent fungi (Antrodia sp. and Coriolus versicolor) shows that (Fig. 2):

- decay resistance is greater for the outer heartwood than the inner heartwood. The effect of radial position is significant for Coriolus versicolor $(p=0.002)$ and Antrodia sp. $(p=0.04)$;

- decay resistance is greater at the top than at the base of the tree. The effect of height is significant for Antrodia sp. ( $p=$ $0.001)$ but not for Coriolus versicolor $(p=0.43)$.

\subsection{Inter-tree variability: effect of geographical origin, effect of tree, effect of radial and height position}

Figure 3 illustrates the mean mass losses of the seventeen trees tested with Antrodia sp. and Pycnoporus sanguineus according locality.

Table II gives the results of correlation $R$ at inter-tree level $(n=17)$ between mass losses of the outer and inner heartwood, tree diameter and sapwood thickness.

Dicorynia guianensis was shown to be more durable to Pycnoporus sanguineus than to Antrodia sp. The results obtained 
Table II. Correlation between diameter, sapwood thickness and mass loss (outer and inner heartwood) - exposition to Antrodia sp. $(n=68)$.

\begin{tabular}{lccc}
\hline & $\begin{array}{c}\text { Mean loss }- \\
\text { outer heartwood }\end{array}$ & $\begin{array}{c}\text { Mean mass loss }- \\
\text { inner heartwood }\end{array}$ & $\begin{array}{c}\text { Tree } \\
\text { diameter }\end{array}$ \\
\hline $\begin{array}{l}\text { Mean mass loss }- \\
\text { outer heartwood }\end{array}$ & 1 & & \\
$\begin{array}{l}\text { Mean mass loss }- \\
\text { inner heartwood }\end{array}$ & $\begin{array}{c}0.04 \\
(\operatorname{Pr}>0.80)\end{array}$ & 1 & \\
$\begin{array}{l}0.44 \\
\text { Tree diameter }\end{array}$ & $\begin{array}{c}0.08 \\
(\operatorname{Pr}=0.07) \\
-0.37\end{array}$ & $\begin{array}{c}0.01 \\
(\operatorname{Pr}=0.96)\end{array}$ & $\begin{array}{c}-0.65 \\
(\operatorname{Pr}=0.004)\end{array}$ \\
Sapwood thickness & $(\operatorname{Pr}=0.14)$ & & \\
\hline
\end{tabular}

here are comparable to those of the study on intra-tree variability; but Antrodia sp. is more destructive on this range of samples than these from the intra tree study. This sample of trees is not very durable with regard to brown rot but it is with regard to white rot (Fig. 3). Radial position effect is significant in a two factors ANOVA "site $\times$ radial position" $(p=0.01)$ and in a two factors ANOVA "tree $\times$ radial position" $(p=0.002)$ for samples exposed to the more destructive fungus Antrodia sp. So, outer heartwood is more resistant than the inner one. In both ANOVA, other factors ("site" and "tree") are not significant with no interaction $(P>0.2)$. Durability of the outer heartwood is slightly correlated with the morphological characteristics of the tree (Tab. II): $R=-0.37$ with sapwood thickness and $R=0.44$ with tree diameter. Thus the greater the diameter of the tree, the thinner the sapwood and the less durable is the wood.

\subsection{Possible use of colour as an indicator of durability - study of intra-tree colour}

Table III shows the mean, standard variation and coefficient of variation of colour parameters. The lightness index $\left(\mathrm{L}^{*}\right)$, whose possible range is from 0 to 100 in the CIELAB colour system, ranges approximately from 44 to 63 (Tab. III). The values for $\mathrm{a}^{*}$ range approximately from 11 to 17 and $\mathrm{b}^{*}$ from 15 to 26 .

Figure 4 gives relation between $\mathrm{L} *$ parameter and $\mathrm{h} *$ parameter and Figures 5, 6 and 7 illustrate the intra-tree variability of colour parameters.

There is a good correlation between $\mathrm{L}^{*}$ and $\mathrm{h} *$ (Fig. 4), and the latter is an important parameter for interpretation of colour. Lightness $\left(\mathrm{L}^{*}\right)$ and hue angle $\left(\mathrm{h}^{*}\right)$ decrease and $\mathrm{C}^{*}$ (saturation) increases (Figs. 5, 6 and 7) as the distance closer to the outermost heartwood diminishes. For $\mathrm{L}^{*}, \mathrm{C}^{*}$ and $\mathrm{h}^{*}$ parameters, radial position and height effect are significant in a two factors

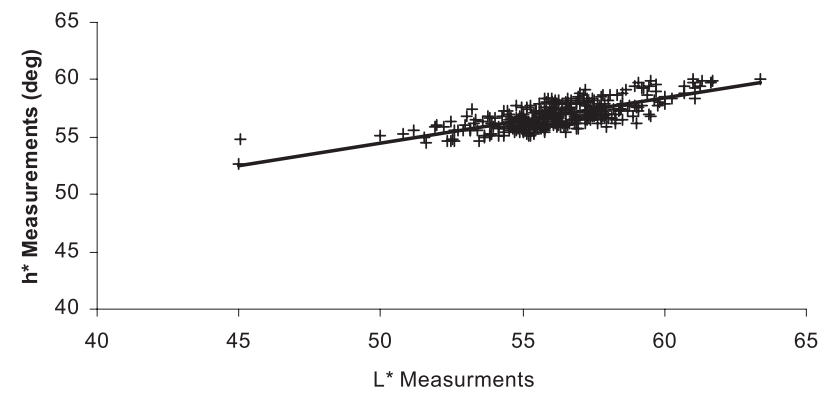

Figure 4. Relation between $\mathrm{L}^{*}$ and $\mathrm{h}^{*}$ colour parameters.

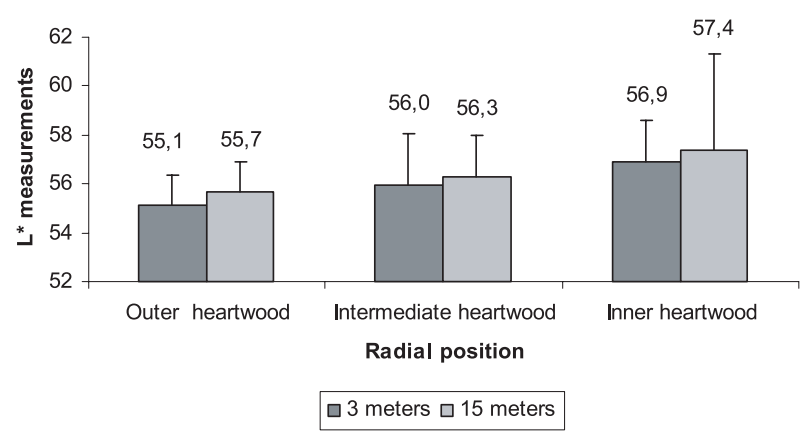

Figure 5. Variation in mean $L^{*}$ with radial position and height.

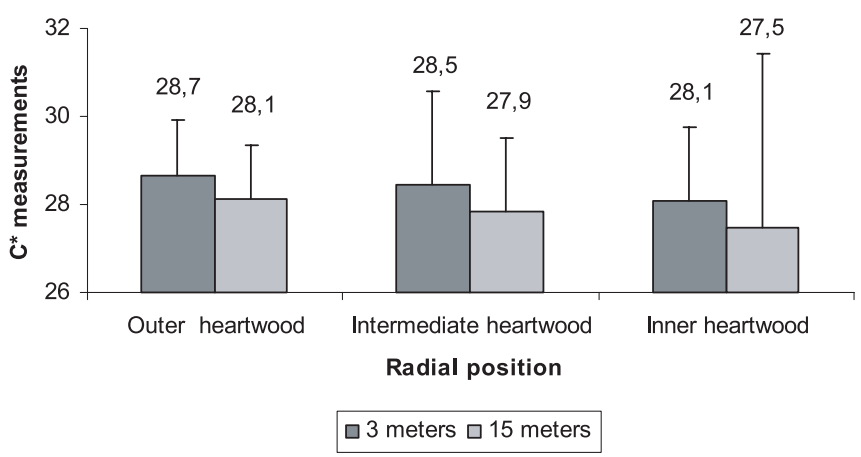

Figure 6. Variation in mean $C^{*}$ with radial position and height.

ANOVA "radial position $\times$ height" $(p<0.0001)$. The variation in $\mathrm{h}^{*}$ measured between the outer and the inner heartwood is visible to the human eye. This means that the colour of the wood becomes lighter and less red near the pith and lightness and hue increase from the base to the top, so the wood is less red and lighter in the upper part of the tree.

Table III. Wood specimen colour in the CIELAB colour system $(n=334)$.

\begin{tabular}{|c|c|c|c|c|c|}
\hline Data & $\mathrm{L}^{*}$ & $\mathrm{a}^{*}$ & $\mathrm{~b}^{*}$ & $\mathrm{C}^{*}$ & $h^{*}$ (degree) \\
\hline Mean & 56.2 & 15.3 & 23.5 & 28.1 & 56.8 \\
\hline Standard variation & 2.1 & 0.6 & 1.0 & 1.0 & 1.1 \\
\hline Coefficient of variation (\%) & 4 & 4 & 4 & 1 & 2 \\
\hline
\end{tabular}




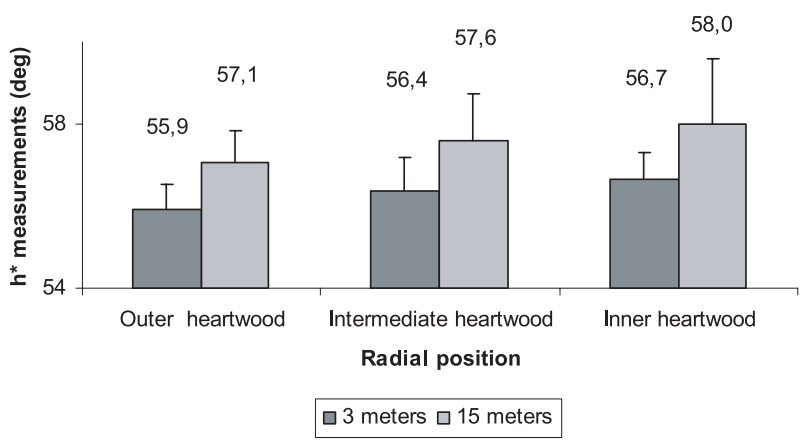

Figure 7. Variation in mean $\mathrm{h}^{*}$ (deg) with radial position and height.

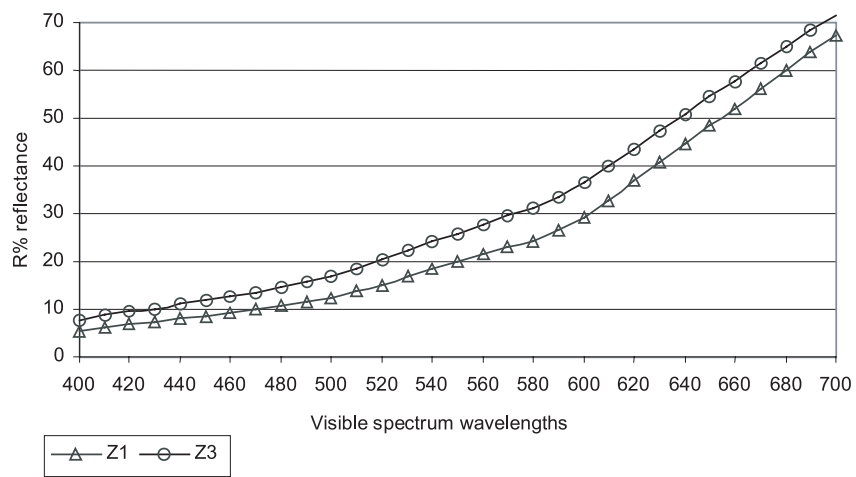

Figure 8. Reflectance of Z1 (outer heartwood) and Z3 (inner heartwood).

Figures 8 and 9 give respectively reflectance of $\mathrm{Z1}$ (outer heartwood) and Z3 (inner heartwood and differences in reflectance between different zone curves.

The absorption decreases with wavelength. It is greater in the outer heartwood (Fig. 8). The values for the difference in reflectance (DR \%) between $\mathrm{Z} 2$ (intermediate zone) and Z3 (inner heartwood), and Z1 (outer heartwood) and Z3 (inner heartwood) show the same maximum DR\% absorbency at $590 \mathrm{~nm}$ (Fig. 9). The colour of the different zones is connected with the total difference in the concentration of organic materials, which absorb the energy of each wavelength over the visible spectrum (400-700 nm). For these reasons, the absorbency in the inner heartwood (Z3) would give the darkest colour but with the same distribution of absorbed light (Fig. 9). The curves of reflectance are parallel but there is a difference between both peaks at $590 \mathrm{~nm}$.

\subsection{Correlation between natural durability and colour parameters}

Tables IV and V show results of correlation $\mathrm{R}$ at intra-tree level $(2 \times n=48)$ between mass losses and colour parameters $\left(\mathrm{L}^{*}, \mathrm{a}^{*}, \mathrm{~b}^{*}, \mathrm{C}^{*}, \mathrm{~h}^{*}\right)$ with both fungi: Coriolus versicolor and Antrodia sp.

Considering the values measured on each sample (from the same tree), there is a correlation between colour parameters $\mathrm{L}^{*}, \mathrm{a}^{*}$ and $\mathrm{h} *$ and decay resistance (Tabs. IV and V) with Coriolus versicolor

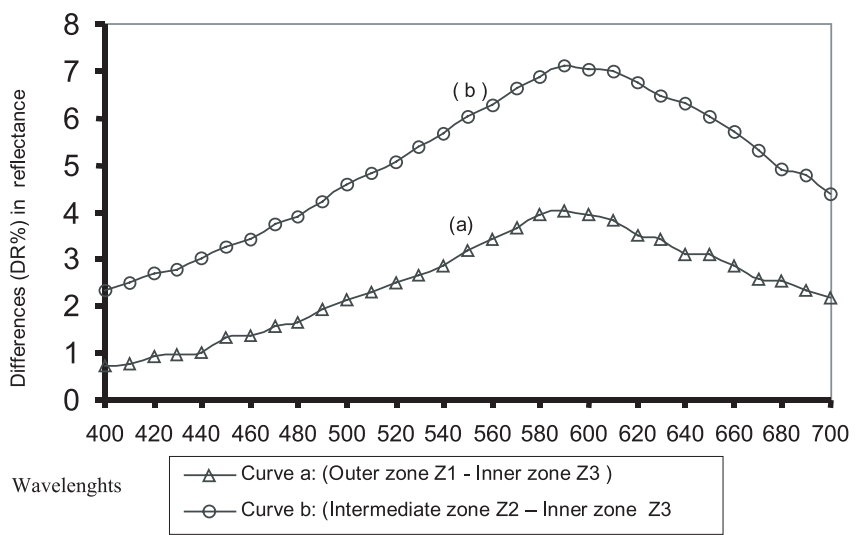

Figure 9. Differences (DR \%) in reflectance between zone curves: (a) Z1 outer $-\mathrm{Z} 3$ inner and (b) Z2 intermediate $-\mathrm{Z} 3$ inner.

Table IV. Correlation between mass loss and colour parameters exposure to Coriolus versicolor.

\begin{tabular}{lccccc}
\hline & $\mathrm{L}^{*}$ & $\mathrm{a}^{*}$ & $\mathrm{~b}^{*}$ & $\left.\mathrm{C}^{*}\right)$ & $\mathrm{h} *(\mathrm{deg})$ \\
\hline Mass loss & 0.30 & -0.44 & 0.05 & -0.11 & 0.42 \\
& $(0.03)$ & $(0.0017)$ & $(0.74)$ & $(0.43)$ & $(0.028)$ \\
Threshold & $(*)$ & $(* *)$ & $($ n.s. $)$ & $($ n.s. $)$ & $(* *)$ \\
\hline
\end{tabular}

Table V. Correlation between mass loss and colour parameters exposure to Antrodia sp.

\begin{tabular}{lccccc}
\hline & $\mathrm{L}^{*}$ & $\mathrm{a}^{*}$ & $\mathrm{~b}^{*}$ & $\left.\mathrm{C}^{*}\right)$ & $\mathrm{h}^{*}(\mathrm{deg})$ \\
\hline Mass loss & -0.06 & 0.14 & -0.08 & -0.004 & -0.19 \\
& $(0.70)$ & $(0.36)$ & $(0.58)$ & $(0.97)$ & $(0.22)$ \\
\multirow{2}{*}{ Threshold } & $($ n.s. $)$ & (n.s.) & (n.s.) & (n.s.) & (n.s.) \\
\hline
\end{tabular}

exposition but not with Antrodia sp. In the case of Coriolus versicolor, the wood is more durable when it is darker and redder.

\section{DISCUSSION}

\subsection{Durability}

Dicorynia guianensis shows important variations in natural durability from one individual to another. The results show that Dicorynia guianensis is much more resistant to white rot than to brown rot. This fact may be explained by the idea put forward by other authors [31, 33, 34], who thought that extractives present in the heartwood may not have the same effect on both types of fungi. For a large number of species, it is widely recognised that natural durability varies depending on the height and on the radial section of the tree $[17,43]$. The intra-tree variability of natural durability was discussed by Rudman in a series of articles entitled "The causes of natural durability in timber" $[35,37-39,41]$ and more recently by other authors such as Viitanen [50] and Hirmke [21]. The behaviour of Dicorynia guianensis tallies with the results obtained with other tropical and 
temperate species. The intra-tree variation in durability in Dicorynia guianensis explains a substantial part of the variability. The large radial variation in resistance to decay shown by many trees is especially noteworthy: the outer heartwood is more durable, with a decrease in durability towards the pith. These results are confirmed by those presented by Déon [13] and Thiel [47] who studied the same species. Decay resistance increases from the base to the top of the tree. However, they do not tally with those of Reis [32], who studied wood species from southeastern Brazil or with those of Zabel [53]. Nevertheless, Hart [18] reported that height effect is not systematic.

Lastly, there is an interesting correlation between sapwood thickness or tree diameter and the durability of the outer heartwood. It is unusual to find a correlation between tree diameter and the durability of the outer heartwood only [6]. As size is usually considered as an indicator of tree age in tropical trees, one could expected a closer correlation with inner heartwood durability, since it integrates time-dependent processes. However, another result of this study is that tree size is connected to an initial durability existing before any extractives ageing process. As there is strong negative correlation between tree diameter and sapwood thickness, it would be interesting to perform further studies with trees of the same age or diameter, to observe a possible intrinsic effect of sapwood thickness linked to duraminisation and growth process.

\subsection{Colorimetry}

Dicorynia guianensis colour in this study was lighter and greyer than that obtained by Nishino [30] for the same species $(\mathrm{L}=39 ; \mathrm{a}=12 ; \mathrm{b}=16)$. This may be explained by the storage conditions: in our study, the wood samples were protected from light during conditioning, as colour is not a stable parameter in time and can be modified by humidity and exposure to light [8]. Our measurements characterised the colour of wood just after sawing (short exposition to light) and drying (12\% moisture content). The most important factor influencing the colour of Dicorynia guianensis was found to be radial position, with the wood becoming less red and lighter near the pith. Finally, our Dicorynia guianensis trees did not behave like European hardwood species such as oak, in which the inner heartwood is redder and darker [22]; nevertheless, this behaviour is not systematic for hardwood species [5]. Colour parameters $L^{*}, C^{*}$ and $h^{*}$ are also influenced by height: the colour becomes less red and lighter in the upper part of the tree. Some researchers have supplemented their studies by monitoring extractives contents from the outer to the inner heartwood, and they showed that they were strongly correlated: quantitative and qualitative extractives contents in the wood influence colour parameters [4]. When studying difference in reflectance between difference zones (inner and outer heartwood), it is important to note the absence of a more or less marked peak. So the differences of colour measurements observed in these zones could be explained by different concentration of extractives between different parts of heartwood rather than the presence of different molecules which absorbed at characteristic wavelength. Thus the reflectance curves are of great interest in understanding the colour of the wood and its relation with extractives content [5]. However, a considerable part of the variability of wood colour cannot be explained.

\subsection{Relation between colour and durability}

Both colour parameters and decay resistance vary from the inner to the outer heartwood. The colour of the heartwood suggests that the compounds in the wood absorb some light wavelengths. However, not all compounds have an effect against fungi, and the occurrence of a dark colour cannot automatically be linked with the presence of the active molecules in biological resistance. It is necessary to study the presence and the chemical nature of the molecules more closely. The function of such compounds in terms of colour cannot simply be associated with natural resistance. However, there may be a correlation between colour and natural durability: biological resistance and wood colour are directly connected with quantitative and qualitative extractives composition $[24,29,40]$. The effects of extractives on wood colour have been studied by several authors [3, 14, $28,29]$. Extracting extractives using suitable solvents modifies wood colour. In the same way, many authors have underlined the direct relationship between durability and extractives $[1,9$, $19,25,33,44,45]$. They have shown that extractives play a key role in the biological resistance of many species $[26,36,46,52]$.

\section{CONCLUSION}

Our results confirm that the natural durability of Dicorynia guianensis varies widely and that it is important to control it because consequences are important for users. They support the following specific conclusions:

1.At intra-tree level, colour parameters are linked with heartwood resistance: the darker and redder the wood, the more resistant it is.

2. Decay resistance in the outer heartwood is related to tree diameter and sapwood thickness: the thinner the sapwood, the greater the tree diameter and the lower the decay resistance.

3. Colour is related to height and radial position in the tree: the wood is darker and redder in the outer heartwood and at the base of the tree.

4.Decay resistance decreases from the outer to the inner heartwood. Variations from the base to the top of the trees are less systematic.

5. There is no effect of locality although the two forest studied are extremely different natural conditions in French Guiana.

All this information can help operators to choose the best wood for the intended end use. This is the fit-for-purpose approach. The influence of the site on natural durability is less important. However, the outer heartwood of medium-diameter trees is more resistant. This information is useful for optimising the period of rotation for forest harvesting: there is a trade-off between yield (big diameter) and quality (natural durability). Moreover, in sawmills, grading of planks for natural durability should take into account log size and radial position inside the log. Grading logs according to geographical criteria before sawing seems less efficient.

Acknowledgements: The authors are extremely grateful to CNES (Centre National d'Études Spatiales), which supported the study and the PhD. Our thanks also go to Christine Baudassé, Alba Zaremsky and Sang Song (CIRAD Forest Products Programme, Montpellier) 
and Patrick Martin and Koese Soepe, Eli Baltus (CIRAD Forest Products Programme, French Guiana), and Olivier Dumonceau (LMGCMontpellier).

\section{REFERENCES}

[1 Anagnost S.E., Smith W.B., Comparative decay of heartwood and sapwood of Red Maple, Wood Fiber Sci. 29 (1997) 189-194.

[2] Bonjour I., Variabilité de la qualité des bois d'une essence guyanaise : l'Angélique Dicorynia guianensis Amsh., Thèse ENGREF, 1996, $314 \mathrm{p}$.

[3] Burtin P., Le déterminisme de la couleur du bois de Chêne. Étude sur les relations entre la couleur et des propriétés physiques, chimiques et anatomiques ainsi que des caractéristiques de croissance, Thèse de $3^{\mathrm{e}}$ cycle en sciences du bois, ENGREF Nancy, 1994, $243 \mathrm{p}$.

[4] Burtin P., Jay-Allemand C., Charpentier J., Janin G., Natural wood colouring process in Juglans sp. (J. nigra, J. regia and hybrid J. nigra $23 \times J$. regia) depends on native phenolic compounds accumulated in the transition zone between sapwood and heartwood, Trees 12 (1998) 258-264.

[5] Burtin P., Jay-Allemand C., Janin G., Relation entre les composés phénoliques solubles du bois de noyer (Juglans regia) et sa couleur, $4^{\mathrm{e}}$ colloque des Sciences et Industries du Bois Nancy, 1996, pp. 107114.

[6] Carrodus B.B., Variability in the proportion of heartwood formed in woody stems, New Phytol. 71 (1972) 713-718.

[7] Cartwright K.S.G., The variability in resistance to decay of the heartwood of home-grown western red cedar (Thuja plicata D. Don) and its relation to position in the log, Forestry 15 (1941) 65-75.

[8] Chang S.T., Wang S., Cheng S.S., Environmental effects on the colour of Sugi (Cryptomeria japonica D. Don) heartwood, J. Wood Sci. 46 (2000) 390-394.

[9] Chang S.T., Wang J.H., Wu C.L., Chen P.F., Kuo Y.H., Comparaison of the antifungal activity of cadinane skeletal sesquiterpenoï from Taiwania (Tawania Crypromerioides Hayara) heartwood, Holzforschung 54 (2000) 241-245.

[10] Da Costa E.W.B., Rudman P., Deverall F.J., Inter-tree variation in decay resistance of Karri (Eucalyptus diversicolor $\mathrm{F}$. Muell) as related to colour, density and extractives content, J. Inst. Wood Sci. 10 (1962) 48-55.

[11] Da Costa E.W.B., Rudman P., Gay F.J., Investigations on the durability of Tectona grandis, Empire Forestry Review 37 (1958) $291-$ 298.

[12] Da Costa E.W.B., Rudman P., Gay J.F., Relationship of growth rate and related factors to durability in Tectona Grandis, Empire Forestry Review 40 (1961) 308-319.

[13] Déon G., A propos de la durabilité naturelle de l'Angélique (Dicorynia guianensis Amsh), CTFT - Note technique 13, 1980, 26 p.

[14]Dumonceau O., Utilisation de petits bois naturellement durables dans des usages extérieurs (aire de jeux, mobilier urbain...) en substitution aux bois traités par des pesticides comme les solutions cuivrechrome-arsenic, Thèse de $3^{\mathrm{e}}$ cycle en sciences du bois, Université de Montpellier II, 2001, $210 \mathrm{p}$.

[15] Freitag C.M., Morrell J., Durability of a changing Western Redcedar resource, Wood Fiber Sci. 33 (2000) 69-75.

[16] Gartner B.L., Morell J.J., Freitag C.M., Spicer R., Heartwood decay resistance by vertical and radial position in Douglas-fir trees from a young stand, Can. J. For. Res. 29 (1999) 1993-1996.

[17] Gominho J., Figueira J., Rodrigues and Pereira H., Within-tree variation of heartwood extractives and wood density in the Eucalyptus hybrid Urograndis (Eucalyptus grandis $\times$ E. Urophylla), Wood Fiber Sci. 33 (2001) 3-8.

[18] Hart J.H., The role of wood exudates and extractives in protecting wood from decay, Chap. 9.2, Rowe J.W. (Ed.), 1981, pp. 861-881.

[19] Hillis W.E., Distribution, properties and formation of some wood extractives, Wood Sci. Technol. (1971) 273-289.
[20] Highley T.L., Scheffer T.C., Natural decay resistance of 30 peruvian woods, USDA Forest Service Research Paper, FPL 143 (1970) 1-5.

[21] Hirmke M., Messner K., Teischinger A., Fellner J., Wimmer R., Influence of felling time on natural durability of Norway Spruce (Picea abies (L.) Karst.), Document IRG WP No 98-10250, 1998, pp. 1-7.

[22] Janin G., Klumpers J., Ducci F., Verracini A., Sevrin E., La couleur du bois des feuillus précieux : Chênes, Noyers, Alisiers, Lignasylva, 1990, pp. 348-355.

[23] Kukachka B.F., Angelique. Revised November, U.S. Products Laboratory Report 1787, 1958, 8 p.

[24] Klumpers J., Le déterminisme de la couleur du bois de Chêne : Étude sur les relations entre la couleur et des propriétés physiques, chimiques et anatomiques ainsi que des caractéristiques de croissance, Thèse de $3^{\mathrm{e}}$ cycle en sciences du bois, ENGREF Nancy, 1994, $195 \mathrm{p}$.

[25] Laks P.E., Wood preservation as trees do it, Scott. For. 45 (1991) 275-284.

[26] Laks P.E., McKaig P.A., Flavonoïd biocides: wood preservatives based on condensed tannins, Holzforschung 42 (1988) 299-306.

[27] Mateejcic B.A., Dicorynia guianensis Amsh. A monograph, Ligna orbis - Serie Internationalis - Royal Tropical Institute Amsterdam, 1974.

[28] Mosedale J.R., Charrier B, Janin G., Genetic control of wood colour density and heartwood ellagitanin concentration in European Oak (Quercus petraea and Q. robur), Forestry 69 (1996) 11-124.

[29] Nelson N.D., Heather W.A., Wood color, basic density, and decay resistance in heartwood of fast grown Eucalyptus grandis Hill ex Maiden, Holzforschung 26 (1972) 54-60.

[30] Nishino Y., Janin G., Chanson B., Détienne P., Gril J., Thibaut B., Colorimetry of wood specimens from French Guiana, J. Wood Sci. 44 (1998) 3-8.

[31] Panayotov P., Roussanov H., Yankoulova S., 3rd ICFWST 97, Fungus resistance of wood species common in Bulgaria, Proceeding book of the 3rd ICFWST, 1997, pp. 164-167.

[32] Reis M.S., Variation in decay resistance of four wood species from Southeastern Brazil, Holzforschung 27 (1973) 103-111.

[33] Rudman P., The causes of natural durability in timber. Pt. VII, The causes of decay resistance in Teak (Tectona grandis L.f), Holzforschung 15 (1961) 151-155.

[34] Rudman P., The causes of natural durability in timber. Pt. IX, The antifungal activity of heartwood extractives in a wood substrate, Holzforschung 16 (1962) 74-77.

[35] Rudman P., The cause of natural durability in timber. Pt. XII, The deterioration in antifungal activity of heartwood extractives during the life of trees of Eucalyptus marginata Sm., Holzforschung 17 (1963) 86-89.

[36] Rudman P., The causes of natural durability in timber. Pt. XI, Some tests on the fungi toxicity of wood extractives and related compounds, Holzforschung 17 (1963) 54-57.

[37] Rudman P., The causes of natural durability in timber. Pt. XVI, The causes of variation in decay resistance in Jarrah (Eucalyptus marginata Sm.), Holzforschung 18 (1964) 172-177.

[38] Rudman P., The causes of natural durability in timber, Pt. XIX Ageing of Eucalyptus heartwoods and its effects on decay resistance, Holzforschung 19 (1965) 190-195.

[39] Rudman P., Da Costa E.W.B., Variation in extractives content and decay resistance in the heartwood of Tectona grandis L.f., J. Inst. Wood Sci. 3 (1959) 33-42

[40] Rudman P., Da Costa E.W.B., The causes of natural durability in timber, Pt. IV, Variation in the role of toxic extractives in the resistance of durable Eucalyptus to decay, Holzforschung 15 (1961) 10-15.

[41] Rudman P., Da Costa E.W.B., Gay J.F., Wood quality in plus trees of Teak (Tectona grandis L.F.). An assessment of decay and termite resistance, Sylvae Genet. 16 (1967) 102-105.

[42] Rudman P., Gay J.F., The causes of natural durability in timber. Pt. XX, The causes of variation in the termite resistance of Jarrah (Euca lyptus marginata Sm.), Holzforschung 21 (1967) 21-23. 
[43] Scheffer T.C., Cowling E.B., Natural resistance of wood to microbial deterioration, Annu. Rev. Phytopathol. 4 (1966) 147-170.

[44] Schultz T.P., Harms W.B., Fisher T.H., Mc Murtrey K.D., Minn J., Nicholas D.D., Durability of Angiosperm heartwood: the importance of extractives, Holzforschung 49 (1995) 29-34.

[45] Smith A.L., Campbell C.L., Diwakar M.P., Hanover J.W., Miller R.O., Extracts from Black Locust heartwood as wood preservatives: A comparison of the methanol extract with pentachlorophenol and chromated copper arsenate, Holzforschung 43 (1989) 421-423.

[46] Suttie E.D., Orsler R.J., The influence of the natural extractives of Opepe (Nauclea diderrichii) and African Padauk (Pterocarpus soyauxii) timbers on their durability, Document IRG WP No 9630098, 1996, pp. 1-15.

[47] Thiel G., Compte rendu des essais effectués sur douze plateaux d'Angélique envoyés par Monsieur Audiard, CTFT, 1982, 21 p.

[48] Vallet A., La filière bois de Guyane - Stratégie de développement. Cabinet Sagital, Cayenne, 2002, 95 p.

[49] Van Acker J., Stevens M., Increased biological durability differs for traditional wood preservation and new non-biocidal systems (NBS), Document IRG WP No. 00-20212, 2000, pp. 1-11.

[50] Viitanen H., Ritschkoff A., Moisture requirements and wood degradation of Pine and Spruce wood by some basidiomycetes - fungi, Document IRG WP No. 1406, 1989, pp. 1-8.
[51] Wangaard F.F., Muschler A.F., Properties and uses of tropical woods., University School of Forestry, Yale University, Newhaven, Connecticut, 1952.

[52] Yatagai M., Takahashi M., Tropical wood extractives effects on durability, paint curing, and pulp sheet resin spotting, J. Inst. Wood Sci. 12 (1980) 176-181.

[53] Zabel R.A., Morell J.J., Wood microbiology - Decay and its prevention, Press Academic Inc, 1992.

\section{STANDARDS}

AFNOR (1992): Norme NF EN 350-1 Durability of wood ad woodbased products - Natural durability of solid wood - part 1: Guide to principles testing and classification of the natural durability of wood.

AFNOR (1994): Norme NF EN 350-1 Durability of wood ad woodbased products - Natural durability of solid wood - part 1: Guide to principles testing and classification of the natural durability of wood. AFNOR (1996): Norme NF-EN 113 Wood preservatives - Test method for determining the protective effectivness against wood destroying basidiomycetes - Determination of the toxic values. 